\title{
PELAKSANAAN UNDANG-UNDANG PERKAWINAN ( STUDY TENTANG TALAK, CERAI DAN POLIGAMI DI KECAMATAN BINAMU KABUPATEN JENEPONTO ) OLEH : SIRAJUDDIN ISMAIL
}

I

Sejak tahun 1928, pergerakan kaum wanita Indonesia membahas tentang praktek perkawinan dalam masyarakat, terutama yang terjadi di kalangan penganut agama Isalm. Pada zaman penjajahan Belanda sudah ada undangundang perkawinan tertulis, yaitu undangundang perdata atau Bulgelijk Wetboek Ordonansi S. 1933-74 jo S. 1936-607, yaitu undang-undang yang berlaku bagi agama Kristen di Jawa, Minahasa dan Amboina. (H Amidhan DKK, TT : 43)

Bagi umat Isalm belum ada undangundang yang mengatur tentang perkawinannya. Hal inilah yang mendorong kaum wanita Indonesia untuk membahas keburukan-keburukan yang terjadi dalam perkawinan umat islam, di antaranya perkawinan di bawah umur, kawin paksa, talak, cerai dan poligami sewenang-wenang serta akibat dari pada perkawinan tersebut. Hal ini terjadi bukan karena tidak ada peraturan dalam Islam yang mengatur hanya orang tidak mentaati aturan tersebut, di sebakkan karena tidak adanya undang-undang perkawinan yang memberi sangsi terhadap mereka yang melanggarnya. (H. Amidhan DKK, TT : 43)

Setelah kemerdekaan Indonesia dan setelah berdirinya Departemen agama di serahi melaksanakan undang-undang No. 22 tahun 1946 tentang nikah, talak dan rujuk, mulanya hanya berlaku di Jawa dan Madura, kemudian dengan undang-undang No. 32 tahun 1954 di berlakukan diseluruh Indonesia, Namun be- lum mengatur materi perkawinan secara lengkap dan sangsi atas pelanggarannya. Usaha memperjuangkan lahirnya undang-undang perkawinan oleh organisasi wanita dan golongan-golongan dalam masyarakat, antara lain oleh ISWI (Ikatan Sarjana Wanita Indonesia), Badan Musyawarah Organisasi Islam Indonesia, Musyawarah BP4.I, ke II dan ke III. 22 Desember 1973, DPR mensyahkan Rencana Undang-Undang RI No. 1 tahun 1974 tentang Perkawinan.

Penelitian ini adalah penelitian tentang undang-undang perkawinan No. 1 tahun 1974 dan peraturan pelaksanaannya PP. No. 9 tahun 1975, dibatasi tentang masalah perceraian, talk dan poligami. Undang-undang perkawinan No. 1 tahun 1974, membedakan putusnya perkawinan antara talak dan cerai, talak adalah putus perkawinan atas inisiatif suami dan dikokohkan oleh pengadilan agama. Cerai adalah putusnya perkawinan atas inisiatif is teri dan dikokohkan oleh pengadilan agama. Poligami adalah perkawinan dari seorang lelaki dengan lebih dari seorang wanita dalam suatu waktu.

Kecamatan Binamu dipilih sebagai daerah penelitian didasarkan pada pertimbangan bahwa kecamatan Binamu terletak di kota Bontosunggu yang merupakan ibukota kabupaten Jeneponto, dimana masyarakatnya adalah masyarakat yang majemuk dan berbeda dengan masyarakat dipedesaan yang bersifat homogen, selain alasan tersebut ternyata angka perceraian di kecamatan Binamu lebih tinggi dibanding dengan kecamatan lain 
di kabupaten Jeneponto.

Pengumpulan data dilaksanakan dengan menggunakan :

1. Wawancara mendalam terhadap pelaksana undang-undang perkawinan, seperti ketua Pengadilan Agama, Kasi, kasub kcpenghuluan Urais, BP4 kabupaten, staf KUA kecamatan (BP4 kecamatan), tokoh agama, tokoh masyarakat dan imam di kecamatan Binamu.

2. Observasi digunakan untuk mengobservasi beberapa aspek kegiatan seperti interaksi sosial, sistem kekerabatan, hubungan kekeluargaan, agama dan sebagainya, juga untuk melengkapi data yang diperoleh melalui wawancara dan kontent analisis.

3. Kontant analisis, digunakan untuk pengumpulan data tertulis (dokumen-dokumen) yang berhubungan dengan pelaksanaan undang-undang perkawinan dan sumbersumber tertulis, kemudian dianalisis dan digeneralisasi sesuai dengan tujuan penelitian.

\section{II}

Kabupaten Jeneponto adalah salah satu daerah kabupaten di propinsi Sulawesi Selatan, $91 \mathrm{~km}$ dari kota Ujung Pandang.

Bcrdasarkan surat keputusan Gubernur Kepala Daerah tingkat I Sulawesi Selatan No. 1100, 16 Agustus 1961, kabupaten Jeneponto dibagi lima kecamatan administrauf dan salah satu di antaranya adalah kecamatan Binamu, luas $150 \mathrm{~km} 2$, tcrdiri dari enam desa, tiga kelurahan, 14 lingkungan, 26 dusun, 120 RK dan 142 RT.

Kecamatan Binamu berpenduduk 61.195 jiwa, pada umumnya mcreka ialah suku Makassar dan menggunakan bahasa Makassar dialek Konjo. Umumnya penduduk bermukim sepanjang pantai, sepanjang jalan raya dan ada pula yang bermukim di daerah perbukitan, mata pencaharian umumnya petani. Kecamatan Binamu memiliki areal tanah persawahan $453.848 \mathrm{Ha}$, tegalan 412.030 Ha dan 602.840 Ha tanah gundul dan kritis. Sarana pendidikan umum terdiri dari, SD 51 buah, SMTP 6 buah, SMTA 6 buah. Sarana kesehatan, sebuah rumah sakit, sebuah Puskemas dan sebuah Balai pengobatan. Program Keluarga Berencana (KB), 7464 PUS, peserta KB 3864 orang $(51,76 \%)$ dengan memakai bermacam-macam alat kontrasepsi. Di bidang perkoperasian, 4 buah KUD dengan 7.421 anggota, 34 buah non KUD dengan 14.784 orang anggota.

\section{III}

Sebagaimana telah dikemukakan bahwa kecamatan Binamu berpenduduk 61.195 jiwa, penganut agama Islam 61.109 jiwa $(99,85 \%)$, Kristen Protestan 83 jiwa dan Hindu 3 jiwa, sedangkan Kristen Katolik dan Budha tidak ada penganutnya. Penganut agama selain

Islam adalah pendatang sebagai pegawai, ABRI dan lain-lain, tidak memiliki tempat ibadah/pemujaan, sedangkan Islam memiliki 49 mesjid, 15 mushalah dan 50 buah langgar. Di dalam pengembangannya Islam memiliki 6 orang ulama, 38 muballig, 46 khatib dan 7 orang pcnyuluh agama. Pendidikan Islam ; 1 diniyah, 2 raodatul atfal, 1 ibtidaiyah swasta, 2 madrasah Tanswiya, 1 Aliyah. Lembaga Daiwah dan pendidikan ; YASPIT, GUPPI, MDI, ALHIDAYAH, DMI dan cebuah lembaga sosial ( Panti Asuhan)

Sistim kekerabatan dan kekeluargaan dalam masyarakat kecamatan Binamu (Makassar). Keluarga luas yaitu kerabat yang di sebut bija pammanakang, yang termasuk dalam keluarga ini dapat diketahui melaui istilah- 
istilah; Boe, nenek/toak, anreng/ammak, mangge, purina, mateang, ammak Ao, bura'ne, baine, sari'battang baine, sari battang bura'ne dan lain-lain hingga minantu dan cucu. Keluarga batih, disebut sipa'anakkang, terdiri dari ayah, ibu dan anak yang belum kawin. Perlu diketahui bahwa rumah tanga suku Makassar pada umumnya tidak hanya ditempati oleh keluarga batih saja, tetapi ikut juga beberapa kerabat yang tergolong bija pammanakkang ( kerabat), misalnya adik ipar, bibi atau mertua dan lain-lain. Dasar yang lebih kuat dari sistim kekerabatan tersimpul dalam konsep siri' dan pacce'. Ada suatu ungkapan dalam masyarakat, ikambe mangkassaraka punna teai siri' pacceseng nipa'bulo sibatangan (kita orang Makassar, kalau bukan karena siri maka paccelah yang membuat bersatu). Disamping konsep itu terdapat pula suatu konsep yang disebut situlung, yaitu kewajiban moral bagi setiap anggota kerabat untuk saling bantu membantu.

Masyarakat kecamatan Binamu menganggap bahwa perkawinan adalah suatu saat yang sangat penting, karena sunnah dan untuk memenuhi kebutuhan biologis ( untuk memperoleh keturunan ), orang yang tidak dikaruniai anak maka putuslah keturunannya ( tau puppusu ), hal ini terkadang membawa kepada bubarnya suatu perkawinan. Anggapan itu dapat dilihat dari tingginya angka perkawinan pada tahun 1988, sejumlah 382 pasang, dilakukan sesuai dengan undang-undang perkawinan dan sesuai dengan hukum Islam. Mereka melakukan perkawianan sesuai dengan hukum Islam, sejak diberlakukannya undang-undang per-kawinan No. 32 tahun 1954, tentang nikah, talak dan rujuk.

\section{IV}

Faktor penunjang dan penghambat pelaksanaannya undang-undang perkawinan dikecamatan Binamu.

Faktor penunjang, adalah kesadaran masyarakat, pada umumnya masyarakat mentaati dan melaksanakan undang-undang perkawinan dan memberi sangsi ( mengusir) bagi masyarakat yuang melakukan perkawinan dibawah tangan ( kawin secara liar ) dan adanya usaha Departemen Agama mengadakan penataran bagi imam-imam walaupun sekali dalam satu atau dua tahun. Sedangkan faktor penghambat :

1. Faktor pendidikan, karena masih rendahnya tingkat pendidikan sebagian masyarakat dipedasaan, sehingga antara lain ada yang mengawinkan anaknya di bawah umur, beralasan telah memenuhi syarat menurut agama.

2. faktor budaya (adat) adanya pelapisan sosial yang ketat, kalau ada dua orang yang ingin kawin tetapi berbeda status sosialnya, terpaksa menempuh jalan minggat.

3. Faktor ekonomi, kebiasaan mengadakan upacara secara besar-besaran merupakan salah satu faktor untuk mempertahankan status sosial dan gensi sosial, keadaan ini yang mewujudkan tuntutan maskawin (sunrang) dan biaya pesta (doe balanja) yang sangat tinggi.

4. Masih ada anggota masyarakat yang sengaja kawin secara liar

5. Faktor tehnis pelaksanaan, antara lain belum intensifnya usaha pemerintah dalam memasyarakatkan undang-undang perkawinan, seperti penataran pelaksanaan undang-undang perkawinan yang diikutsertakan dalam jumlah yang masih terbatas

Dengan diberlangsungkan undang-undang perkawinan No. 1 tahun 1974, maka peranan BP4 menjadi semakin penting karena dapat berfungsi dalam penasehatan perselisihan maupun penasehatan perkawinan, sebagai

No. 1 \& 2 Thn. I Juli / Desember 1990 
mana Keputusan Menteri Agama RI No. 30 tahun 1977, BP4 sebagai konsultan yang memberi bantuan penasehatan kepada masyarakat, baik bagi mereka yang ingin dan telah memasuki kehidupan rumah tangga, maupun bagi mereka yang menghadapi krisis rumah tangga. Penasehatan sebelum perkawinan, yaitu bagi calon suami isteri seperti calon pengantin yang belum pern ah kawin, calon pengantin yang berpengalaman calon pengantin yang akan berpoligami, Penasehatan sesudah kawin yaitu penasehatan dihadapan kedua mempelai, baik setelah ijab qabul maupun dalam pesta perkawinan. Penasehatan setelah terjadi krisis rumah tangga dimulai dari imam hingga BP4 kabupaten. Disamping itu peranan imam yang paling penting adalah peranannya di dalam menyelesaikan masalah minggat (anyala), terutama wanita erangkale.

Sebab-sebab terjadinya talak dan cerai di kecamatan Binamu, disebabkan oleh beberapa faktor yaitu, krisis akhlak, biologis dan ekonomi. Cerai 13 kasus $(3,40 \%) ; 8$ kasus $(61,53 \%)$ karena faktor ekonomi, 4 kasus $(30,76 \%)$ karena krisis akhlak dan 1 kasus $(7,69 \%)$ karena ekonomi dan biologis. Talak 3 kasus $(0,78 \%) ; 2$ kasus $(66,66 \%)$ karena krisis akhlak dan 1 kasus $(33,33 \%)$ karena faktor ekonomi. Poligami 2 kasus $(0,52 \%)$, faktor penyebab poligami adalah faktor budaya, sebagaimana telah dikemukakan bahwa dasar yang kuat dalam seluruh kehidupan suku
Makasssar tersimpul dalam konsep siri' dikecamatan Binamu poligami disebabkan karena wanita erangkale, bila wanita merasa dipermalukan atau disinggung harkat kemanusiaannya (siri').

Dampak sosial akibat talak dan cerai, terhadap anak antara lain, tidak ada tokoh-tokoh ideal yang dapat dicontoh dalam perkembangan kepribadian anak, anak merasa rendah diri terhadap lingkungannya, fustrasi karena merasa orang tuanya tidak lengkap dan termasuk problema sosial ekonomi. Demikian pula terhadap keluarga kedua belah pihak akan renggang. Sedangkan dampak sosial dari pada poligami ; Dampak positif, memenuhi ketenangan psikologis dan harapan masa depan keluarga yang lebih kongkrit. Bila suatu perkawinan tidak dikaruniai anak dan suami ingin memperoleh anak tanpa merusak perkawinannya dengan isteri pertama maka satusatunya jalan adalah poligami. .

Dampak negatif, dari segi psikologis bahwa hampir seluruh wanita tidak ada yang mau dimadu. Namun kawin secara poligami dikecamatan Binamu memperoleh izin dari isterinya.

Suami lebih banyak berlaku tidak adil, mungkin seorang bisa adil kalau dalam masalah material, namun dari segi batiniah seorang suami sering menghadapi kendala-kendala psikologis. 


\section{DAFTAR KEPUSTAKAAN}

Amidhan H. DKK, BP4 Pertumbuhan \& Perkembangan, Pengurus BP4, Jakarta.

Abd. Muthalib Drs, Laporan Pengumpulan

Data Peninggalan sedan Purbakala Kabupaten Jeneponto, Suaka Peninggalan sejarah dan Purbakala, Sulawesi Selatan.

Anwar nazir Tanjung, Nasehat Perkawinan No. 81 Desember, Pustaka Antara, Jakarta.

Departemen Pendidikan Dan Kebudayaan, Adat dan Perkawinan Bugis Makassar, Proyek Penelitian dan Pencatatan Kebudayaan Daerah, Jakarta.

Hanafiah Sabil, Kawin Lari Sebuah Study Kasus Tentang Perubahan Sosial Dalam Maysarakat Jeneponto Sulawesi Selatan, PLPIS, Ujung Pandang.
Mattulada Drs, Bugis Makassar Manusia Dan Kebudayaan, Universitas Indonesia, Jakarta.

Mukhlis, Dimensi Sosial Kawasan Pantai, P3MP UNHAS, Makassar.

Munir SA H.M. Drs. DKK, Pendoman Pencatat Nikah, Proyek Pembinaan Sarana Keagamaan Islam, Jakarta.

Natsir Said Mr. M, Siri' Dan Hubungannya Dengan Perkawinan di Masyakat Mangkasara Sulawesi Selatan.

Tedjasukmana, Nasehat Perkawinan No. 63, Pustaka Antara Jakarta.

Tamar Djaja, Tuntunan Perkawinan \& Rumah Tangga Islam $1 \mathrm{Al}$ Ma'arif, Bandung. 